Department of Economics- FEA/USP

\title{
Domestic Tourism and Regional Inequality in Brazil
}

EDUARDO A. HADDAD ALEXANDRE A. PORSSE WILSON RABAHY

Working PAPER SERIES № 2011-07 


\title{
Domestic Tourism and Regional Inequality in Brazil
}

\author{
Eduardo A. Haddad (ehaddad@usp.br) \\ Alexandre A. Porsse (porsse@gmail.com) \\ Wilson Rabahy (rabahy@usp.br)
}

Research Group: NEREUS - Núcleo de Economia Regional e Urbana

\begin{abstract}
:
This paper analyses the consumption patterns of tourists coming from different domestic origins and choosing other domestic destinations in Brazil, in terms of expenditure level and composition. We also look at different alternatives of financing tourist expenditures and their implications for the net multipliers in an integrated framework. We use survey data for domestic tourism in Brazil to consolidate an interregional matrix of expenditures by tourists. We then use an interregional inputoutput system for Brazil to compute the tourism multipliers effects based on alternative hypotheses for the sources of financing of expenditures by tourists. The results are analyzed and their implications for regional inequality in the country are discussed.
\end{abstract}

Keywords: Regional impact analysis of tourism; interregional input-output model;

Tourism expenditure multipliers; domestic tourism; regional inequality Brazil

JEL Codes: C67, L83, R11. 


\title{
Domestic Tourism and Regional Inequality in Brazil
}

\author{
Eduardo A. Haddad, Alexandre A. Porsse and Wilson Rabahy
}

\begin{abstract}
This paper analyses the consumption patterns of tourists coming from different domestic origins and choosing other domestic destinations in Brazil, in terms of expenditure level and composition. We also look at different alternatives of financing tourist expenditures and their implications for the net multipliers in an integrated framework. We use survey data for domestic tourism in Brazil to consolidate an interregional matrix of expenditures by tourists. We then use an interregional inputoutput system for Brazil to compute the tourism multipliers effects based on alternative hypotheses for the sources of financing of expenditures by tourists. The results are analyzed and their implications for regional inequality in the country are discussed.
\end{abstract}

\section{Introduction}

The tourism sector has been gaining prominence as potential foundations for regional economies which lack traditional primary and secondary activities, on one hand, and offer special natural, cultural and historical attractions, on the other hand. Such locations have been able to attract revenue from tourists in the same way as production that is exported (Malecki, 1991). From a regional perspective, such export market is not only associated with potential consumers from other countries, but also consumers from other regions within the country. Such broader perspective allows us to distinguish between international and domestic tourists, both of them as potential sources of income injections in a regional economy.

The focus of this paper is on domestic tourism. We analyze the consumption patterns of tourists coming from different domestic origins and choosing other domestic destinations in Brazil, in terms of expenditure level and composition. We also look at different alternative of financing tourist expenditures and their implications for the net multipliers in an integrated framework.

How does the observed pattern of domestic tourist expenditures contribute to regional inequality in Brazil? Do peripheral regions benefit from a net transfer of resources from the more developed regions? To address these issues, we will use an interregional input- 
output accounting-based approach incorporating data from a comprehensive national survey on domestic tourism in Brazil. Results suggest domestic tourism acts in favor of reducing regional inequality in the country. When proper compensating financing mechanisms are taken into consideration, the Northeast region is the net gainer from the existing pattern of domestic tourists expenditures, while the Southeast provides most of the interregional income transfers.

In the next section, we provide further motivation for the proposed topic, reviewing the relevant literature. We then present the methodology used in the research in Section 3. It adds to the traditional single-region input-output approach, often used in regional tourism impact analysis, the complexity of an integrated interregional system. Section 4 describes the domestic tourism survey used to calibrate the matrix of household expenditures with domestic tourism. The simulation design is then described and results are presented in section 5. Final remarks follow.

\section{Motivation}

As the economic base of a region, activity in the tourism sector provides the main factor determining the overall level of activity in the region, sustained by demand outside the region. Widely used as the underlying theoretical framework of impact models to explain how tourism activities generate regional income (e.g. Bonn, 2008; Pacaud et al., 2007; Smeral, 2005; Tyrrell and Johnston, 2006), the base theory sums up to the concept of the base multiplier, which can be considered as a crude form of regional income multiplier that neglects many of the general equilibrium effects needed to better understand the repercussionary effects of an expansionary process on interregional trade (Richardson, 1969).

Insofar as the tourism sector is the relevant economic base, the income injections are frequently associated with international and domestic tourist expenditures in the local economy. Even though there is a great deal of variation about the magnitude of their impact, often estimated using input-output models, there is little doubt on their positive income and employment generating effects on the destination regions (van Leeuwen et al., 2009). 
Many geographically peripheral regions, which have attractive scenery and much history but little industrial base, have been encouraged to view tourism as a current and future foundation upon which to build an economic base. The disadvantage of such a strategy is its limited [positive] income-generating potential. Employment in tourism is often seasonal; it is also often relatively low paid. Moreover, multipliers from tourism typically are greatly reduced by leakages. As a result the multiplier effects generated for the local regional economy by tourism tend to be restricted (Temple, 1994). Whether the benefits of tourism as an economic base are equivalent to those of other sectors depends on the degree of linkage within or leakage from the regional economy. Despite uncertainties over benefits, tourism is an alluring source of income to struggling countries [and regions] (Malecki, 1991).

In the context of integrated interregional systems, this is certainly true for international tourists expenditures. Channeling injections of income from abroad to specific regions of a country may still be seen as a process of high probability of activating the multiplier effect in those areas - again, despite uncertainties about its magnitude and potential crowding-out effects associated with resources constraints (Blake, 2009).

However, for domestic tourism, there is considerable doubt about its net benefits for the country and its regions. The main reason is that, from a spatial perspective, domestic tourists expenditures are supposed to be accompanied by foregone consumption in the tourists' residence region. Whether leisure travels are financed by foregone current or future consumption (i.e. reductions in savings), there are potential crowding-out effects in the system as a whole. National effects will depend mostly on the composition of the expenditures, both the direct purchases by tourists in the destination regions and the associated multiplier effects. Compared to consumption profiles at the residence regions, there may be negligible differences in total national income effects.

The more interesting question that arises is related to the role played by domestic tourism as a mechanism of interregional transfers of income. There exist many intergovernmental systems through which income is redistributed between regions with different levels of wealth. Economic theory suggests such redistribution might be distorting. Compared to inter-governmental transfers, such as equalization grants, domestic tourism can be considered as a more efficient mechanism of interregional 
transfers, as consumer decisions to travel may be seen as fully based on an optimality problem in which preferences and price signals play a key role, without imposing further market distortions. Moreover, even the use of the more realistic approach of decision-making process of tourists based on random-utility theory (Mansfeld, 1992) does not provoke market distortions.

The specialized literature is aware of the potential impacts of domestic tourism on regional inequality in a country (e.g. Baidal, 2003, 2004; Krakover, 2004; Lasanta et al., 2007; Pacaud et al., 2007; Seckelmann, 2002; Whitford, 2009). Also, tourism multiplier studies often emphasize the differential regional growth potential associated with tourism activities in the study area (van Leeuwen et al., 2009). However, tourism impact studies tend to overestimate the regional effects of domestic tourism as they often rely on single-region models. Such modeling approach fails to recognize in an operational way the interconnections between regions. The one region of interest is essentially "disconnected" from the rest of the country within which it is located (Miller and Blair, 2009). This precludes the operation of the before mentioned financing mechanism related to foregone consumption in the origin region. One rare exception is the study for Denmark (Zhang et al., 2007), in which a (international and domestic) tourism submodel is presented together with the Danish interregional general equilibrium model LINE. The study of the regional tourism multipliers do take into consideration interregional feedbacks from tourism expenditures but does not consider potential crowding-out effects through financing of tourism expenditures.

In this paper we will look at domestic tourism in an integrated interregional system in the case of Brazil, a country characterized by strong regional inequalities. The degree of regional concentration and inequality in Brazil can be gauged from Table 1, which shows the share of each region in GDP and the proportion of the average per capita GRP of each region to the national average per capita GDP. In 2008, the Northeast's GRP was $13.1 \%$ of the national GDP, while the North's GRP reached only $5.1 \%$ of the national total. In terms of inequality, while the Northeast presented an average per capita GRP 53.2\% below the national average, and the North reached only $63.9 \%$, the other regions, especially the Southeast, showed indicators substantially above the national average. These differences in regional wealth are accompanied by impressive differences in regional social indicators as well, which can be summarized by the 
estimates of the Human Development Index (HDI) for the Brazilian states and regions, also presented in Table 1.

$$
<\text { Insert Table } 1 \text { here >> }
$$

According to estimates by FIPE (2009), the Northeast, the poorest region in Brazil, is one of the main destinations for domestic tourists in the country. Almost $20 \%$ of domestic trips for tourism purposes in 2007 had the Northeast states as the final destinations, which injected in the region about one third of total domestic tourists expenditures. Considering that the region was responsible for $13.1 \%$ of national GDP, these figures show the prominent position of the region as a tourist destination for Brazilians. On the other hand, the main origin region of travelers was the Southeast region (over $56 \%$ of total domestic trips originated in the region), whose residents were responsible for $54 \%$ of the total tourists expenditures in the country. As evidenced by these flows, domestic tourism could be an important channel of income transfers from the richest regions to the poorest regions in Brazil. Thus, the relevance of such a channel is investigated in a quantitative systemic perspective using an interregional input-output approach. It is expected that this analysis reveals the extent to which the interaction between domestic tourist expenditures and interregional interdependence contributes for reducing regional inequality in Brazil.

\section{Methodology}

The conventional input-output model is given by the system of matrix equations:

$$
x=A x+f
$$

$x=(I-A)^{-1} f=B f$

where $x$ and $f$ are respectively the vectors of gross output and final demand; $A$ consists of input coefficients $a_{i j}$ defined as the amount of product $i$ required per unit of product $j$ (in monetary terms), for $i, j=1, \ldots, \mathrm{n}$; and $B$ is known as the Leontief inverse. 
Let us consider systems (1) and (2) in an interregional context, with $R$ different regions, so that:

$x=\left[\begin{array}{c}x^{1} \\ \vdots \\ x^{R}\end{array}\right] ; A=\left[\begin{array}{ccc}A^{11} & \cdots & A^{1 R} \\ \vdots & \ddots & \vdots \\ A^{R 1} & \cdots & A^{R R}\end{array}\right] ; f=\left[\begin{array}{c}f^{1} \\ \vdots \\ f^{R}\end{array}\right] ;$ and $B=\left[\begin{array}{ccc}B^{11} & \cdots & B^{1 R} \\ \vdots & \ddots & \vdots \\ B^{R 1} & \cdots & B^{R R}\end{array}\right]$

and

$x^{1}=B^{11} f^{1}+\cdots+B^{1 R} f^{R}$

$\vdots$

$x^{R}=B^{R 1} f^{1}+\cdots+B^{R R} f^{R}$

Let us also consider different components of $f$, which include household expenditures with domestic tourism, $v$, other household expenditures, $c$, and other final demand expenditures, $e$. We obtain information of domestic tourist expenditures from the domestic tourism module, allowing us to treat $v$ as a matrix which provides the monetary values of expenditures of tourists coming to domestic region $r$ from domestic region $s$.

$v=\left[\begin{array}{ccc}v^{11} & \cdots & v^{1 R} \\ \vdots & \ddots & \vdots \\ v^{R 1} & \cdots & v^{R R}\end{array}\right] ; c=\left[\begin{array}{c}c^{1} \\ \vdots \\ c^{R}\end{array}\right] ; \quad e=\left[\begin{array}{c}e^{1} \\ \vdots \\ e^{R}\end{array}\right]$

Thus, we can re-write (4) as:

$x^{1}=B^{11}\left(v^{11}+\cdots+v^{R 1}+c^{1}+e^{1}\right)+\cdots+B^{1 R}\left(v^{1 R}+\cdots+v^{R R}+c^{R}+e^{R}\right)$

$\vdots$

$x^{R}=B^{R 1}\left(v^{11}+\cdots+v^{R 1}+c^{1}+e^{1}\right)+\cdots+B^{R R}\left(v^{1 R}+\cdots+v^{R R}+c^{R}+e^{R}\right)$

With (5), we can then compute the contribution of expenditures with domestic tourism on regional output. It is clear from (5) that regional output depends, among others, on domestic tourist expenditures in the region, and, depending on the degree of interregional integration, also on domestic tourist expenditures outside the region. 
More specifically, we will concentrate our analysis on the contribution of $v$ to $x$, examining the systemic effects of the consumption patterns of tourists coming from different domestic origins and choosing other domestic destinations in Brazil, in terms of expenditure level and composition. ${ }^{1}$ We will also look at different alternative of financing tourist expenditures and their implications for the net multipliers in an integrated framework. Given regional households budget constraints, resources allocated to tourism activities crowd out other types of consumption (present or future). Thus, we will examine two alternative hypotheses for the sources of financing of expenditures by tourists: (i) reductions in personal savings, considering only the systemic effects of $v$, which gives the upper bound for the multiplier effects of expenditures in the short run in this modeling context, and (ii) simultaneous monetaryequivalent reductions in consumption in the respective origin regions, representing an induced substitution effect in the consumption basket of travelers according to household consumption patterns provided in $c$.

\section{Domestic Tourism in Brazil: Expenditures Patterns}

The most recent source of comprehensive information on domestic tourism in Brazil for the purpose of our paper is the study "Caracterização e dimensionamento do turismo doméstico no Brasil - 2007”. Based on a series of over 37,000 interviews with urban households using a randomized sampling design focusing on potential travelling households, it includes detailed regional information on the social status of the travellers, on their motives to travel, on their origins and destinations, the length of stays, and on the distribution of their spending on different items such as accommodation, restaurants, transportation, entertainment, etc. The survey was commissioned by the Ministry of Tourism in Brazil and was conducted by the Institute of Economic Research Foundation - FIPE - from the University of Sao Paulo.

From the existing types of households tips considered in the survey - routine trips, excursion/one-day trips, international trips, and domestic trips - only the latter was considered in our calculations (stay visitors). Therefore, the concept of domestic tourism in our study relates only to domestic trips reported by households with at least

\footnotetext{
${ }^{1}$ Similarly, we could further decompose $e$ in order to extract information on international tourist expenditures in Brazil.
} 
one overnight stay in the destination $(39.4 \%$ of the interviewed households engaged in this type of travel).

Insofar that the survey's focus is on domestic tourism, especially the demand side, we were able to organize the micro data and expand the sample in such a way to generate the necessary information to consolidate a matrix of origin-destination expenditure profiles at the macro-regional level for the year 2007, and, thus, calibrate the matrix $v$ (Table 2).

$$
<\text { Insert Table } 2 \text { here }>>
$$

Table 2 presents a global picture of the regional structure of expenditures by domestic tourists in Brazil. From an accounting perspective, it provides a first order approximation of the direct effects of tourists expenditures. Considering interregional balances of expenditures, two macro regions in Brazil (Northeast and South) presented positive net balances, i.e. total tourists expenditures in the region (columns totals) exceeded residents expenditures engaged in tourism activities in other regions (rows totals). It is important to notice that these figures include intraregional flows which, for most regions, represent the main source of domestic tourism income.

\section{Simulations Design and Results}

Results of the economic impacts of domestic tourism on gross output are discussed in this section, taking into account their regionally disaggregated effects. Typical short run impacts are caused by tourist expenditures of consumer goods and services in the destination regions. Such impacts appear due to greater levels of production (through the use of available idle capacity in the productive system) and may be ranked as: a) direct impacts, which include those economic categories directly affected by the economic activities that are mobilized through tourists expenditures, such as accommodation, restaurants, transportation, entertainment, etc., and b) indirect impacts, which result from additional effects of intersectoral and interregional purchases needed to meet the final demand generated by tourists. The spatial distribution of such multiplier effects - i.e. their distribution through the regional and national economies is dependent on the several structural, locational and cultural factors. 
We used equation (5) to evaluate the role played by each origin-destination tourist flow in generating the model's results. For each regional interaction, we calculated its contribution to the total outcome in terms of national and regional gross output. We first examined the national effects. We then looked at the effects on regional inequality, through the differential impacts on gross regional output for the five Brazilian macro regions (North, Northeast, Southeast, South and Center-West).

\section{National impacts}

Tables 3-5 present the results for national gross output. As previously mentioned, we have considered two different sets of hypotheses for the sources of financing of the expenditures by domestic tourists: (i) reductions in savings, and (ii) foregone consumption in the residence region. While Table 3 presents the impacts of tourism expenditures considering typical input-output total effects based on the information of matrix $v$ and the Leontief inverse, Table 4 shows the total impacts of the hypothetical foregone home consumption. Table 5 sums up the results of Tables 3 and 4 to provide the net multiplier effects, which include short-run resources constraints in the system. Tourists expenditures associated with domestic tourists flows between and within macro regions are explicitly considered, and the estimates of their contributions to national outcome are presented.

$$
\begin{aligned}
& <\text { Insert Table } 3 \text { here }>> \\
& <<\text { Insert Table } 4 \text { here }>> \\
& <<\text { Insert Table } 5 \text { here }>>
\end{aligned}
$$

The positive effect of tourism on national gross output reported in Table 3 is associated with the case in which tourists' consumption is financed by reductions in savings. This result suggests that domestic tourism could be an important channel to increase output and income in the whole country. But if we take into account that, given budget constraints, domestic tourists' expenditures are to be financed by consumption reductions in the tourists' residence region, the positive effects are offset by negative substitution effects, reported in Table 4. Then, the results presented in Table 5 suggest the net effect of domestic tourism on national gross output is small. Re-allocation of 
households' expenditures from their home regions to the touristic destination regions generated only BRL 589.07 millions in 2007, which represents $3.3 \%$ of total tourists expenditures in the same year. This result is driven by differences in the composition of the alternative budget allocations, as well as the associated import leakages.

\section{Regional Impacts}

Tables 6-10 present the results for the gross output of each one of the five regions in the model. The net total effects on national gross output shown in Table 5 are now decomposed into the specific effects in each region.

A similar pattern appears in all tables: positive net regional output effects are associated with tourists expenditures in the region, while the substitution effects that arise when residents travel to other regions generate negative net impacts on regional output. Moreover, tourism flows not directly linked to the region also tend to generate negative impacts on regional output; essentially, regional production is affected through interregional linkages.

Distributional effects of domestic tourism are evident. In net terms, there appear relevant transfers to the Northeast from the remaining regions, mainly the Southeast. The net total effect of tourists expenditures is negative but very small for the North, South and Center-West. For instance, the net total effect reaches only $-0.5 \%$ of total tourists expenditures in the North, and $-6.6 \%$ and $-11.6 \%$ respectively for the South and Center-West. On the other hand, the net total effect of tourists expenditures reaches BRL 4,998.37 millions for the Northeast, which is $87.6 \%$ of the total tourists expenditures in that region. In opposition, the result for the Southeast is a significantly negative net total effect which reaches BRL $-4,023.29$ millions $(-59.9 \%$ of the total tourists expenditures in that region). Such results show that domestic tourism does produce a redistributive effect of income from the richest region to the poorest region in Brazil.

These results indicate that impact multipliers of tourism activity can be very different among regions. As domestic tourists expenditures are financed by foregone consumption in the tourists' origin region, some regions can present output gains from 
tourism activity while other regions can present net losses like in a competition game. The sign and magnitude of the regional impact multipliers are conditioned both by the tourists' consumption decisions in the destination and origin regions and the complexity of interregional linkages among regions. In summary, what the analysis carried out for the Brazilian economy has shown is that total impact of domestic tourists expenditure could be approximate by a zero-sum game at the national level but not necessarily at the regional level. And, most important, domestic tourism seems to play a non-distortionary role in order to improve regional inequality in Brazil.

$$
\begin{aligned}
& \text { < Insert Table } 6 \text { here }>> \\
& <<\text { Insert Table } 7 \text { here }>> \\
& <<\text { Insert Table } 8 \text { here }>> \\
& <<\text { Insert Table } 9 \text { here }>> \\
& <<\text { Insert Table } 10 \text { here }>>
\end{aligned}
$$

\section{Final remarks}

The results of this paper suggest that total net multiplier effects of domestic tourism at national level lead to a zero-sum game but regional distributive effects are significant. Then, domestic tourism can be considered as an important channel to produce a more efficient allocation of resources and reduce inequality among regions in Brazil.

Such results were achieved based on the use of a comprehensive national survey on domestic tourism and a detailed interregional input-output system. From a methodological point of view, the use of a national survey integrated to an interregional input-output system eliminates the often encountered problem in local and regional studies associated to the absence of any control total data for tourist expenditures figures in an integrated system (Archer, 1984, 1995).

The study also adds to the understanding of the net impacts of domestic tourism multipliers as it considers the important issue of household (tourists) decisions under budget constraints. By introducing the foregone home consumption effects in our calculations, a better approximation of the impacts are accomplished. It should be mentioned though that such issue of financing household expenditures in tourism is not 
ignored at all in impact studies. The more and more frequent use of CGE models in impact studies does consider resources constraints and price effects (Zhou et al., 1996). However, to our knowledge, most of the applications are restricted to national and regional CGE models, which do not provide the adequate treatment of tourism flows in a fully integrated spatial setting.

Our exercise was based on the less flexible input-output framework. Even though our methodological choice still brings important limitations, it was able to highlight the role played by the interdependence among regions in the context of domestic tourism. However, to investigate the impact of domestic tourism on regional inequality there is a need to go one step further and develop interregional CGE models which deals not only with regional interaction within a country and spatial feedbacks, but also explicitly consider broader resource constraints and price effects.

\section{References}

Archer, B. H. (1984), Economic Impact: Misleading Multiplier, Annals of Tourism Research, Vol 11, No 3, pp 517-518.

Archer, B. H. (1995). Economic Impact Analysis. Research Notes and Reports, University of Surrey, UK, pp. 704-707.

Baidal, J. A. I. (2003). Regional Development Policies: An Assessment of their Evolution and Effects on the Spanish Tourist Model. Tourism Management Vol 24, pp. $655-663$.

Baidal, J. A. I (2004). Tourism Planning in Spain: Evolution and Perspectives. Annals of Tourism Research, Vol 31, No 2, pp. 313-333.

Blake, A. (2009). The Dynamics of Tourism's Economic Impact. Tourism Economics, Vol 15, No 3, pp. 615-628.

Bonn, M. A. (2008). A Comparison of Three Economic Impact Models for Applied Hospitality and Tourism Research, Tourism Economics, Vol 14, No 4, pp. 769-789.

FIPE (2008). Caracterização e Dimensionamento do Turismo Doméstico no Brasil. Final Report. Embratur/Ministério do Turismo, Brasília. (in Portuguese)

Krakover, S (2004). Tourism Development - Centres versus Peripheries: The Israeli Experience during 1990's. The International Journal of Tourism Research, Vol 6, No 2, pp.97-111. 
Lasanta, T., Laguna, M. and Vicente-Serrano, S. M. (2007). Do Tourism-based Ski Resorts Contribute to the Homogeneous Development of the Mediterranean Mountains? A Case Study in the Central Spanish Pyrenees. Tourism Management, Vol 28, pp. 1326-1339.

Malecki, E. J. (1991). Technology and Economic Development: The Dynamics of Local, Regional and National Change. Longman Scientific and Technical, New York.

Mansfeld, Y. (1992). From Motivation to Actual Travel. Annals of Tourism Research, Vol 19, pp. 399-419.

Miller, R. E. and Blair, P. D. (2009). Input-Output Analysis: Foundations and Extensions. Cambridge University Press, Cambridge, Second Edition.

Pacaud, L., Vollet, D. and Angeon, V. (2007). Impact of Tourism Infrastructure on Regional Development: The Implantation of a Center Parcs Resort in Northern France. Tourism Economics, Vol 13, No 3, pp. 389-406.

Richardson, H. W. (1969). Regional Economics: Location Theory, Urban Structure, Regional Change. Praeger Publishers, New York.

Seckelmann, A. (2002). Domestic Tourism: A Chance for Regional Development in Turkey? Tourism Management, Vol 23, No 1, pp. 85-92.

Smeral, E (2005). The Economic Impact of Tourism beyond Satellite Accounts. Tourism Analysis, Vol 10, pp. 55-64.

Temple, M. (1994). Regional Economics. St. Martin’s Press, London.

Tyrrell, T. J. and Johnston, R. J.(2006). The Economic Impacts of Tourism: A Special Issue. Journal of Travel Research, Vol 45, pp. 3-7.

Van Leeuwen, E. S., Nijkamp, P. and Rietveld, P. (2009). A Meta-analytic Comparison of Regional Output Multipliers at Different Spatial Levels: Economic Impacts of Tourism. In: A. Matias, P. Nijkamp and M. Sarmento (eds.). Advances in Tourism Economics: New Developments. Physica-Verlag, Heidelberg.

Whitford, M (2009). A Framework for the Development of Event Public Policy: Facilitating Regional Development. Tourism Management, Vol. 30, pp. 674-682.

Zhang, J., Madsen, B. and Jensen-Butler, C. (2007). Regional Economic Impacts of Tourism: The Case of Denmark. Regional Studies, Vol 41, No 6, pp. 839-853.

Zhou, D., Yanagida, J. F., Chakravorty, U. and Leung, P. S. (1996). Estimating Economic Impacts from Tourism. Annals of Tourism Research, Vol 24, No 1, pp. 7689. 
Table 1. Gross Domestic Product (GDP), Gross Domestic Product per capita and Human Development Index (HDI) for Brazilian states and regions

\begin{tabular}{lccc}
\hline & GDP $2008^{a}$ & GDP per capita $2008^{b}$ & ${\text { HDI } 2000^{c}}$ \\
BRAZIL & $\mathbf{1 0 0 . 0}$ & & $\mathbf{0 . 7 6 6}$ \\
NORTH & & $\mathbf{1 0 0 . 0}$ & $\mathbf{0 . 7 2 2}$ \\
Rondônia & $\mathbf{5 . 1}$ & $\mathbf{6 3 . 9}$ & 0.735 \\
Acre & 0.6 & 74.9 & 0.697 \\
Amazonas & 0.2 & 61.9 & 0.713 \\
Roraima & 1.5 & 87.6 & 0.746 \\
Pará & 0.2 & 74.1 & 0.723 \\
Amapá & 1.9 & 50.0 & 0.753 \\
Tocantins & 0.2 & 69.0 & 0.710
\end{tabular}

\section{NORTHEST}

Maranhão

Piauí

Ceará

Rio Grande do Norte

Paraíba

Pernambuco

Alagoas

Sergipe

Bahia

\section{SOUTHEAST}

Minas Gerais

Espírito Santo

Rio de Janeiro

São Paulo

SOUTH

Paraná

Santa Catarina

Rio Grande do Sul

\section{CENTER-WEST}

Mato Grosso do Sul

Mato Grosso

Goiás

Distrito Federal

\section{1}

1.3

0.6

2.0

0.8

0.8

2.3

0.6

0.6

4.0

56.0

9.3

2.3

11.3

33.1

16.6

5.9

4.1

6.6

9.2

1.1

1.7

2.5

3.9
46.8

0.681

38.2

33.6

44.5

51.3

42.9

50.4

38.9

61.2

52.4

132.5

89.0

126.5

135.2

153.0

114.2

105.9

127.4

114.9

127.4

88.7

112.1

80.5

287.5
0.636

0.656

0.700

0.705

0.661

0.705

0.649

0.682

0.688

0.803

0.773

0.765

0.807

0.820

0.805

0.787

0.822

0.814

0.788

0.778

0.773

0.776

0.844

${ }^{a}$ Proportion of the GDP of each state/region to the national GDP output.

${ }^{b}$ Proportion of the GDP per capita of each state/region to the national GDP per capita output.

${ }^{c}$ The HDI of each region was calculated by the average of the HDI states normalized by population.

Source: Brazilian Institute of Statistics and Geography (IBGE) and Institute for Applied Economic Research (IPEA). 
Table 2. Domestic Tourists Expenditures in Brazil, by Origin-Destination Flows (in BRL millions)

\begin{tabular}{|c|c|c|c|c|c|c|c|}
\hline & & \multicolumn{5}{|c|}{ Destination } & \multirow{2}{*}{ Total } \\
\hline & & North & Northeast & Southeast & South & Center-West & \\
\hline \multirow{6}{*}{.5 } & North & 316,77 & 212,51 & 263,59 & 63,62 & 136,57 & 993,07 \\
\hline & Northeast & 61,51 & $1.438,24$ & 751,57 & 110,59 & 110,60 & $2.472,51$ \\
\hline & Southeast & 163,07 & $3.124,31$ & $4.947,93$ & 814,07 & 517,31 & $9.566,69$ \\
\hline & South & 20,93 & 349,62 & 397,42 & $2.163,94$ & 113,16 & $3.045,07$ \\
\hline & Center-West & 81,53 & 579,21 & 360,34 & 266,72 & 384,24 & $1.672,05$ \\
\hline & Total & 643,81 & $5.703,89$ & $6.720,86$ & $3.418,95$ & $1.261,88$ & $17.749,39$ \\
\hline
\end{tabular}


Table 3. Gross Total Effects of Tourists Expenditures on National Output, by Origin-Destination Flows (in BRL millions)

\begin{tabular}{|c|c|c|c|c|c|c|c|}
\hline & & \multicolumn{5}{|c|}{ Destination } & \multirow{2}{*}{ Total } \\
\hline & & North & Northeast & Southeast & South & Center-West & \\
\hline \multirow{6}{*}{ : } & North & 502,57 & 342,13 & 420,72 & 104,08 & 220,64 & $1.590,14$ \\
\hline & Northeast & 99,73 & $2.314,97$ & $1.232,59$ & 181,28 & 181,29 & $4.009,85$ \\
\hline & Southeast & 267,88 & $5.088,38$ & $8.269,18$ & $1.352,49$ & 856,17 & $15.834,10$ \\
\hline & South & 34,28 & 562,09 & 637,82 & $3.577,41$ & 187,18 & $4.998,78$ \\
\hline & Center-West & 132,71 & 940,87 & 594,80 & 438,77 & 629,49 & $2.736,64$ \\
\hline & Total & $1.037,17$ & $9.248,44$ & $11.155,11$ & $5.654,02$ & $2.074,76$ & $29.169,50$ \\
\hline
\end{tabular}

Table 4. Total Effects of Foregone Home Consumption on National Output, by Origin-Destination Flows (in BRL millions)

\begin{tabular}{|c|c|c|c|c|c|c|c|}
\hline & \multicolumn{5}{|c|}{ Destination } & \multirow{2}{*}{ Total } \\
\hline & & North & Northeast & Southeast & South & Center-West & \\
\hline \multirow{6}{*}{ 竞 } & North & $-507,33$ & $-340,36$ & $-422,16$ & $-101,90$ & $-218,73$ & $-1.590,47$ \\
\hline & Northeast & $-97,84$ & $-2.287,70$ & $-1.195,47$ & $-175,91$ & $-175,93$ & $-3.932,86$ \\
\hline & Southeast & $-262,46$ & $-5.028,37$ & $-7.963,37$ & $-1.310,20$ & $-832,57$ & $-15.396,97$ \\
\hline & South & $-33,91$ & $-566,55$ & $-644,01$ & $-3.506,61$ & $-183,38$ & $-4.934,46$ \\
\hline & Center-West & $-132,91$ & $-944,20$ & $-587,41$ & $-434,79$ & $-626,37$ & $-2.725,68$ \\
\hline & Total & $-1.034,44$ & $-9.167,18$ & $-10.812,43$ & $-5.529,41$ & $-2.036,97$ & $-28.580,44$ \\
\hline
\end{tabular}

Table 5. Net Total Effects of Tourists Expenditures on National Output, by OriginDestination Flows (in BRL millions)

\begin{tabular}{|c|c|c|c|c|c|c|c|}
\hline & & \multicolumn{5}{|c|}{ Destination } & \multirow{2}{*}{ Total } \\
\hline & & North & Northeast & Southeast & South & Center-West & \\
\hline \multirow{6}{*}{ 表 } & North & $-4,75$ & 1,77 & $-1,44$ & 2,18 & 1,91 & $-0,34$ \\
\hline & Northeast & 1,88 & 27,27 & 37,12 & 5,37 & 5,36 & 76,99 \\
\hline & Southeast & 5,42 & 60,01 & 305,81 & 42,29 & 23,60 & 437,13 \\
\hline & South & 0,37 & $-4,47$ & $-6,19$ & 70,80 & 3,80 & 64,32 \\
\hline & Center-West & $-0,20$ & $-3,32$ & 7,39 & 3,98 & 3,12 & 10,96 \\
\hline & Total & 2,73 & 81,26 & 342,68 & 124,61 & 37,79 & 589,07 \\
\hline
\end{tabular}


Table 6. Net Total Effects of Tourists Expenditures on Regional Output of the North, by Origin-Destination Flows (in BRL millions)

\begin{tabular}{|c|c|c|c|c|c|c|c|}
\hline & & \multicolumn{5}{|c|}{ Destination } & \multirow{2}{*}{ Total } \\
\hline & & North & Northeast & Southeast & South & Center-West & \\
\hline \multirow{6}{*}{ 䨌 } & North & 217,11 & $-110,40$ & $-139,95$ & $-33,67$ & $-71,21$ & $-138,12$ \\
\hline & Northeast & 72,37 & $-56,78$ & $-37,73$ & $-5,39$ & $-4,52$ & $-32,05$ \\
\hline & Southeast & 199,04 & $-13,79$ & $-55,25$ & $-9,49$ & $-2,19$ & 118,32 \\
\hline & South & 25,45 & $-1,16$ & $-5,34$ & $-20,61$ & $-0,28$ & $-1,95$ \\
\hline & Center-West & 97,41 & $-14,92$ & $-12,66$ & $-9,11$ & $-9,97$ & 50,75 \\
\hline & Total & 611,38 & $-197,05$ & $-250,94$ & $-78,27$ & $-88,17$ & $-3,05$ \\
\hline
\end{tabular}

Table 7. Net Total Effects of Tourists Expenditures on Regional Output of the Northeast, by Origin-Destination Flows (in BRL millions)

\begin{tabular}{|c|c|c|c|c|c|c|c|}
\hline & \multicolumn{5}{|c|}{ Destination } & \multirow{2}{*}{ Total } \\
\hline & & North & Northeast & Southeast & South & Center-West & \\
\hline \multirow{6}{*}{ 竞 } & North & $-35,71$ & 254,28 & $-41,66$ & $-10,10$ & $-19,40$ & 147,41 \\
\hline & Northeast & $-53,20$ & 641,43 & $-684,75$ & $-101,04$ & $-99,20$ & $-296,78$ \\
\hline & Southeast & 2,71 & $4.147,47$ & $-111,15$ & $-25,97$ & $-7,81$ & $4.005,26$ \\
\hline & South & 0,68 & 467,28 & $-5,52$ & $-27,08$ & 0,41 & 435,76 \\
\hline & Center-West & $-1,16$ & 752,70 & $-20,84$ & $-16,78$ & $-17,21$ & 696,72 \\
\hline & Total & $-86,68$ & $6.263,16$ & $-863,92$ & $-180,96$ & $-143,22$ & $4.988,37$ \\
\hline
\end{tabular}

Table 8. Net Total Effects of Tourists Expenditures on Regional Output of the Southeast, by Origin-Destination Flows (in BRL millions)

\begin{tabular}{|c|c|c|c|c|c|c|c|}
\hline & \multicolumn{5}{|c|}{ Destination } & \multirow{2}{*}{ Total } \\
\hline & & North & Northeast & Southeast & South & Center-West & \\
\hline \multirow{6}{*}{ 离 } & North & $-105,72$ & $-79,52$ & 260,43 & $-21,89$ & $-40,76$ & 12,54 \\
\hline & Northeast & $-11,63$ & $-365,25$ & 862,34 & $-23,59$ & $-14,61$ & 447,26 \\
\hline & Southeast & $-180,56$ & $-3.623,75$ & $1.063,87$ & $-928,95$ & $-551,45$ & $-4.220,84$ \\
\hline & South & $-3,39$ & $-81,55$ & 447,50 & $-455,06$ & $-14,26$ & $-106,77$ \\
\hline & Center-West & $-29,61$ & $-240,86$ & 349,66 & $-105,07$ & $-129,60$ & $-155,48$ \\
\hline & Total & $-330,92$ & $-4.390,93$ & $2.983,81$ & $-1.534,55$ & $-750,69$ & $-4.023,29$ \\
\hline
\end{tabular}


Table 9. Net Total Effects of Tourists Expenditures on Regional Output of the South, by Origin-Destination Flows (in BRL millions)

\begin{tabular}{|c|c|c|c|c|c|c|c|}
\hline & & \multicolumn{5}{|c|}{ Destination } & \multirow{2}{*}{ Total } \\
\hline & & North & Northeast & Southeast & South & Center-West & \\
\hline \multirow{6}{*}{.5 } & North & $-55,39$ & $-43,23$ & $-54,57$ & 73,96 & $-24,27$ & $-103,50$ \\
\hline & Northeast & $-3,41$ & $-126,29$ & $-63,63$ & 141,09 & $-6,62$ & $-58,85$ \\
\hline & Southeast & $-12,56$ & $-348,03$ & $-461,52$ & $1.031,68$ & $-41,78$ & 167,78 \\
\hline & South & $-21,98$ & $-379,42$ & $-430,32$ & 626,59 & $-119,18$ & $-324,31$ \\
\hline & Center-West & $-11,50$ & $-100,47$ & $-59,56$ & 319,47 & $-55,61$ & 92,33 \\
\hline & Total & $-104,85$ & $-997,44$ & $-1.069,59$ & $2.192,79$ & $-247,46$ & $-226,56$ \\
\hline
\end{tabular}

Table 10. Net Total Effects of Tourists Expenditures on Regional Output of the Center-West, by Origin-Destination Flows (in BRL millions)

\begin{tabular}{|c|c|c|c|c|c|c|c|}
\hline & & \multicolumn{5}{|c|}{ Destination } & \multirow{2}{*}{ Total } \\
\hline & & North & Northeast & Southeast & South & Center-West & \\
\hline \multirow{6}{*}{. } & North & $-25,04$ & $-19,36$ & $-25,69$ & $-6,13$ & 157,55 & 81,33 \\
\hline & Northeast & $-2,24$ & $-65,83$ & $-39,11$ & $-5,71$ & 130,31 & 17,42 \\
\hline & Southeast & $-3,20$ & $-101,89$ & $-130,14$ & $-24,97$ & 626,82 & 366,62 \\
\hline & South & $-0,38$ & $-9,61$ & $-12,51$ & $-53,04$ & 137,12 & 61,58 \\
\hline & Center-West & $-55,34$ & $-399,78$ & $-249,23$ & $-184,53$ & 215,52 & $-673,35$ \\
\hline & Total & $-86,20$ & $-596,47$ & $-456,68$ & $-274,38$ & $1.267,33$ & $-146,40$ \\
\hline
\end{tabular}

